\title{
Perencanaan Energi Listrik Alternatif Tenaga Air Laut Dengan Menggunakan Magnesium Sebagai Anoda Untuk Penerangan Alternatif Pada Kapal Nelayan
}

\author{
Dwiki Novditya Bagaskara Utama, Indra Ranu Kusuma, Sardono Sarwito \\ Teknik Sistem Perkapalan,Fakultas Teknologi Kelautan, Institut Teknologi Sepuluh Nopember (ITS) \\ Jl. Arief Rahman Hakim, Surabaya 60111 Indonesia

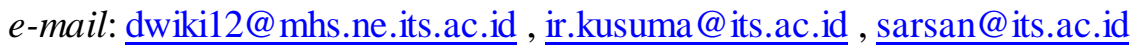

\begin{abstract}
Abstrak-Nelayan sangat membutuhkan penerangan saat berlayar untuk mencari ikan pada malam hari. Energi listrik alternatif diperlukan untuk mengurangi kerja dari generator pada kapal nelayan. Salah satunya adalah dengan memanfaatkan air laut dengan bantuan menggunkan magnesium sebagai anoda sehingga bisa menciptakan suatu sumber listrik yang disebut elektrokimia. Sumber daya kimia biasanya mengadopsi logam aktif sebagai anoda untuk memberikan elektron. Metode pengujian yang igunakan adalah dengan memvariasikan katoda-katoda serta dengan memvariasikan volume air laut. Selain itu digunakan pula rangkaian listrik tunggal,seri dan pada penelitian. Untuk penggunaan katoda lebih efisien dengan menggunakan katoda carbon dimana memiliki nilai tegangan 1,92 $\mathrm{V}$ dan efisiensi sebesar 83,84 \%. Sedangkan Untuk mengcover lighting di navigation deck selama 11 jam memerlukan sebanyak 69 blok cell yang dipararelkan, dimana setiap blok cell terdiri dari 13 cell yang diserikan serta mengkonsumsi daya sebesar 3408,6 Wh. Dimensi prototype untuk yang direncanakan adalah sebesar $130 \mathrm{~cm}$ x $175 \mathrm{~cm}$ x $20 \mathrm{~cm}$ dan berat prototype ditambah air laut adalah $690,69 \mathrm{Kg}$.
\end{abstract}

Kata Kunci- Anoda, Katoda, Listrik Alternatif, Magnesium, Nelayan

\section{PENDAHULUAN}

$\mathrm{E}$ NERGI listik alternatif sangat diperlukan sebagai penerangan alternatif pada kapal-kapal nelayan guna menekan pengeluaran nelayan salah satunya adalah dengan memanfaatkan air laut dengan menggunkan magnesium sebagai anoda. Magnesium merupakan logam yang bisa digunakan sebagai sumber daya kimia. Magnesium adalah unsur kimia dalam tabel periodikyang memiliki simbol $\mathrm{Mg}$ dan nomor atom 12 serta berat atom 24,31.[1] Sumber daya kimia biasanya mengadopsi logam aktif sebagai anoda untuk memberikan elektron. Selama proses discharge, anoda kehilangan elektron dan larut ke elektrolit dalam bentuk ion logam .[2] Sementara itu, elektron dikirim melalui sirkuit eksternal untuk menghasilkan energi . Dengan demikian, sumber daya tersebut dipengaruhi oleh anoda logam, yang memainkan peran penting dalam menentukan tegangan sel. [4] Magnesium adalah logam yang sangat menjanjikan sebagai bahan anoda karena kinerja bawaan yang baik .

Sebenarnya, ada beberapa bahan logam yang bisa digunakan sebagai anoda yaitu $\mathrm{Zn}, \mathrm{Fe}, \mathrm{Al}, \mathrm{Mg}$. Dalam hal ini, dipilih magnesium sebab magnesium belum terlalu tereksplore ke khalayak umum.[3] Dimana memiliki reaksi kimia bila bereaksi dengan katoda dan larutan elektrolit adalah sebagai berikut :

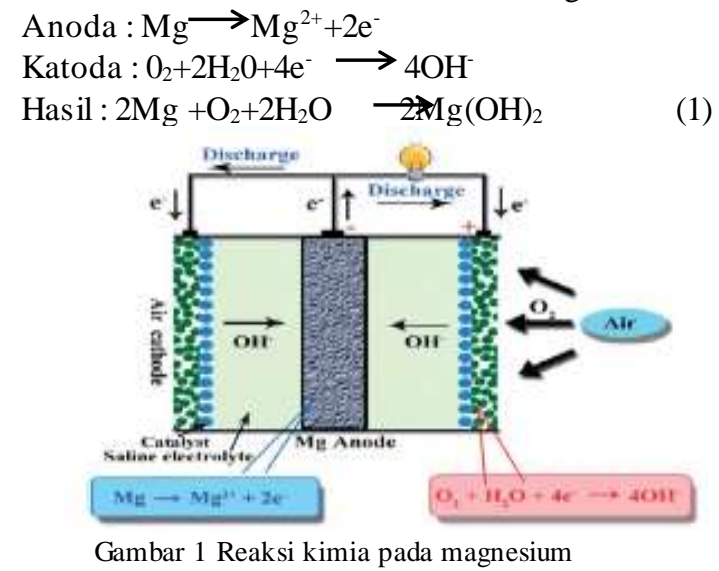

\section{A. Studi Literatur}

\section{METODOLOGI PENELITIAN}

Sebelum memulai pengerjaan Tugas Akhir (TA) dilakukan study literature dengan mencari literature-literatur mengenai pembangkit listrik alternatif dengan memanfaatkan magnesium dimana berupa jurnal,paper, hasil penelitian, buku-buku baik versi cetak maupun versi online. Dimana pada tahap ini merumuskan segala sesuatu yang akan dilakukan pada Tugas Akhir ini sesuai dengan referensi-referensi yang dimiliki.

\section{B. Desain Awal Prototype Listrik Alternatif Untuk Ujicoba} Awal

Tahap ini merupakan tahap pendesainan prototype dengan menggunakan software. Pendesaian dilakukan supaya alat memiliki bentuk awal sebagai bahan ujicoba utuk mendapatkan data-data sesuai dengan yang akan diujikan. Prototype yang direncanakan adalah berbentuk box berukuran pxlxt $=15 \mathrm{~cm}$ x15 $\mathrm{cm} \times 15 \mathrm{~cm}$ dan terbuat dari bahan akrilik. 


\section{Pembuatan Prototype Pembangkit Listrik Alternatif}

Setelah dilakukan pendesaianan menggunakan software, dilakukan pembuatan alat dengan bahan-bahan yang sudah ditentukan . Dimaan wadah akan terbuat dari bahan akrilik dan setidaknya muat paling tidak untuk 2 liter air laut.

\section{Pengecekan Bahwa Alat Telah Terangkai Secara Tepat}

Tahap ini merupakan pengecekan secara fisik dan visual pada alat yang dirancang baik dari segi pemasangan komponen ataupun pemasangan kabel-kabel pada alat.

\section{E. Pemasangan Peralatan dan Pengisian Air Laut}

Pada tahap ini dilakukan pemasangan peralatan-peralatan seperti kabel, anoda dan katoda serta avometer. Sedangkan untuk air laut yang diletakkan pertama kali adalah sebanyak 500 $\mathrm{ml}$. Setelah ini mulai ditambah dengan range $500 \mathrm{ml}$.

\section{F. Pengecekan terhadap adanya listrik atau tidak}

Secara teori setelah anoda dan katoda diletakkan, maka akan timbul energy listrik yang disebut sel volta akibat reaksi elektrokimia. Pada tahap ini merupakn tahap pengujian alat dengan cara mengetes awal dengan menggunakan avometer. Jika saat diuji terdapat listrik, maka dapat diakatan alat siap diuji, namun jika tidak maka perlu dilakukan lagi pengecekan alat

\section{G. Percobaan}

Pada tahap ini adalah melakukan percobaan terhadap alat yang dibuat. Variable yang diberikan adalah

\section{Variable Kontrol}

Variable yang dibuat sama pada penelitiam dimana pada percobaan ini adalah dimensi magnesium, dan dimensi wadah.

\section{Variabel bebas}

Variabel yang divariasikan adalah volume air laut yang digunakan sebagai elektrolit sel-Volta serta jumlah lilitan, dan ketebalan lilitan pada tembaga sebagai katoda

Variabel Terikat

Variabel terikat merupakan variable yang tergantung pada variable bebas yaitu tegangan dan arus yang teramati pada multimeter

\section{H. Pengambilan data}

Melakukan pengambilan data dan pencatatan data yang merupakan hasil dari variable terikat,diamana akan dilakukan analisis dan penarikan kesimpulan menganai alat ini.

\section{Analisa data}

Melakukan analisa terhadap data yang didapat, dimana yang dianalaisa seperti pengaruh volume air laut, pengaruh jenis-jenis katoda, dan lama waktu bisa menyala.

\section{J. Perencanaan Alat Untuk Pengaplikasian}

Tahap ini merupakan tahap pendesaian akhir, dimana setelah diketahui karakteristik dari alat dilakukan pendesaianan baik dimensi maupun fungsi kerja alat yang sesuai untuk kebutuhan. Serta dilakukan pembuatan alat sesuai dengan hasil pendesaianan.

\section{K. Penarikan Kesimpulan}

Pada tahap akhir adalan dilakukan penarikan kesimpulan. Dalam tahap ini akan mengetahui bagaimana dari hasil alat yang direncanakan apakah sudah sesuai target atau tidak.

\section{Pembuatan Laporan}

Setelah proses Peneliatian dilakukan pembuatan laporan, diamana laporan berisi tentang hasil analisi dari prototype yang diciptakan.

\section{A. Hasil Variasi Anoda}

- Mg-Cu (Magnesium-Tembaga)

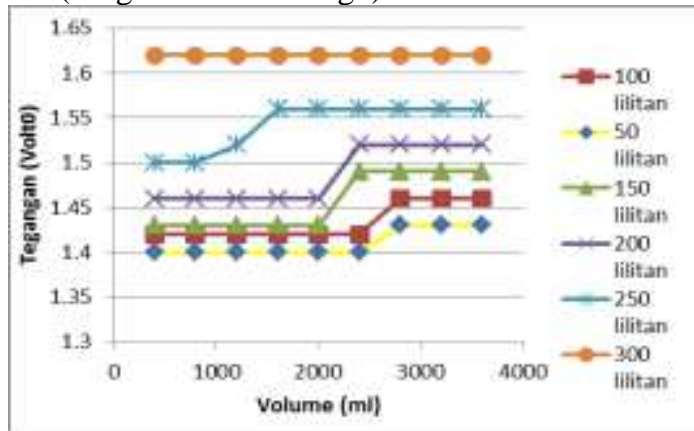

Gambar 2 Hubungan antara tegangan dan arus pada jumlah lilitan yang berbeda

Berdasarkan gambar 2 menunjukkan pengaruh volume air laut terhadap tegangan tidak terlalu dapat dilihat, hal tersebut terbukti baik pada jumah lilitan 50,100,150,200 ,dan 250 mengalai kenaikan pada titik penambahan volume $2000-3000 \mathrm{ml}$ tidak sampai mengalami kenaikan tegangan sebesar 1 volt.

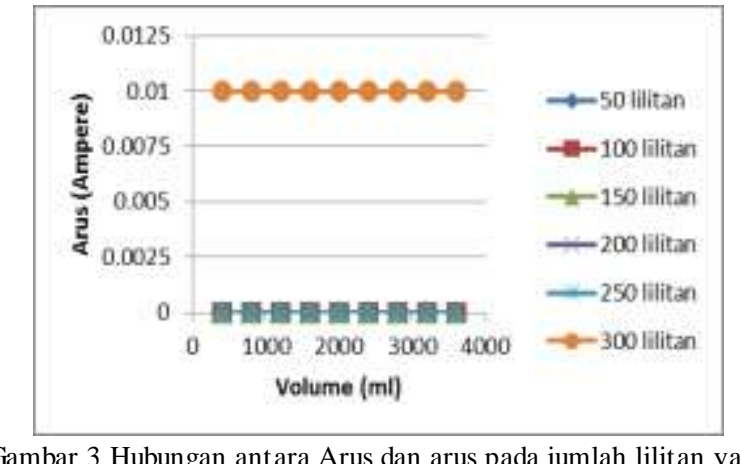

Gambar 3 Hubungan antara Arus dan arus pada jumlah lilitan yang berbeda

Pada gambar 3 dapat dkaetahui bahwa volume air laut tidak berpengaruh terhadap besarnya arus. Namun besar arus dapat terbaca pada jumlah lilitan 300 lilitan, sedangkan lainnya tidak terbaca arusnya.

Berdasarkan hukum faraday 1 :

$\mathrm{Q}=\mathrm{I} x \mathrm{t}, \operatorname{dan} \mathbf{Q}=\mathrm{n} \mathrm{F}$

Maka, $\mathrm{Ixt}=\mathrm{nxF}, \mathrm{I}=\mathrm{nxF} / \mathrm{t}$

Dimana $\mathrm{I}=$ arus, $\mathrm{t}=$ waktu, $\mathrm{n}=$ jumlah mol elektron (mol), $\mathrm{F}$

$=$ muatan listrik per 1 mol elektron (coulomb $/ \mathrm{mol}$ ).

Dalam hal ini semakin banyak mol yang bereaksi,maka akan membuat arus akan bertambah. Hal ini terbukti hanya dengan menggunakan katoda tembaga yang jumlah lilitannya lebih banyak 


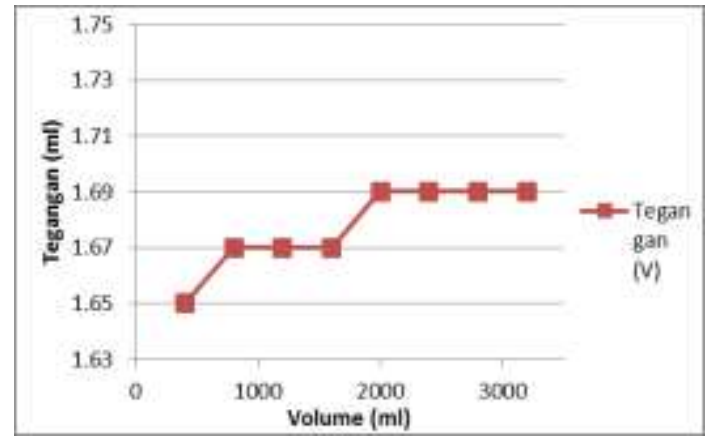

Gambar 4 Hubungan antara tegangan dan arus pada copper rod tunggal

Pada gambar 4 pengaruh volume air laut terhadap tegangan tidak terlalu terpengaruh. Hal tersebut terlihat dimana hanya terjadi kenaikan hanya sebesar 0,02 V.Pada saat ketinggian maksimum atau volume maksimum dari air laut hanya mampu menghasilkan sebesar 1,69 V.

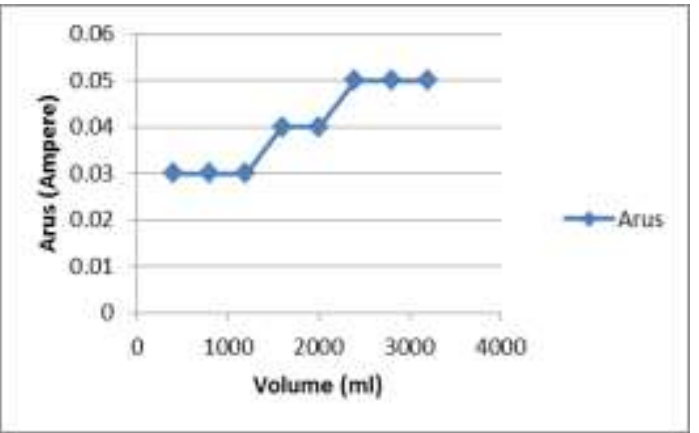

Gambar 5 Hubungan antara tegangan dan arus pada copper rod tunggal

Pada gambar 5 dapat dkaetahui bahwa pengaruh volume air laut berpengaruh terhadap besarnya nilai arus. Dimana terjadi kenikan dua kali sebesar 0,01 A sampai pada akhirnya mencapai arus puncak yaitu sebesar 0,05 A.

- $\mathrm{Mg}-\mathrm{Pb}$ (Magnesium-Timbal)

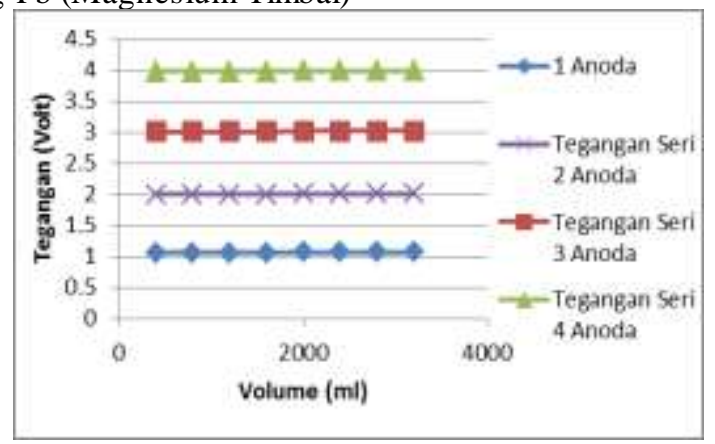

Gambar 6 Hubungan Antara Volume Air dan Tegangan pada Rangkaian Seri Timbal

Pada gambar 6 pengaruh volume air laut terhadap tegangan tidak berpengaruh. Dimana grafik terbentuk secara linear. Sedangkan nilai tegangan pada masing-masing percobaan seri 2, 3, dan 4 anoda menaiki kenaikan sebesar 1,15-1,3 V

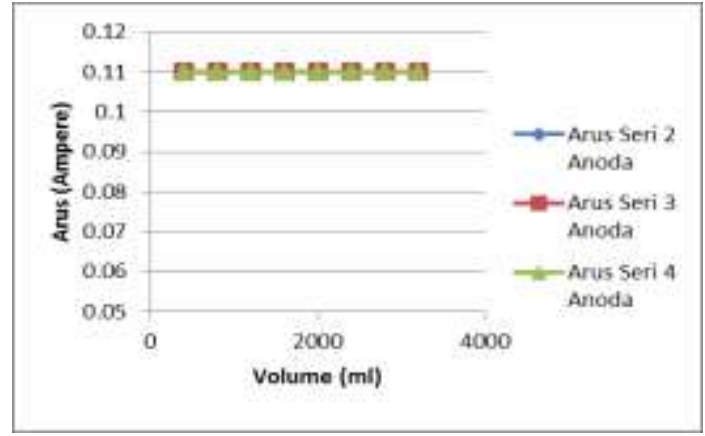

Gambar 7 Hubungan Antara Volume Air dan Arus pada Rangkaian Seri Timbal

Pada gambar 7 pengaruh volume air laut terhadap Arus tidak berpengaruh. Dimana grafik berbentuk linear, dimana ketika volume air ditambahkan maka nilai arus tidak akan berubah.. Sedangkan nilai arus pada masing-masing percobaan seri 2, 3, dan 4 anoda tidak mengalami kenaikan berdasarkan dari hukum kirchoff. Dimana arus tidak akan mengalami kenaikan pada suatu rangkaian seri.

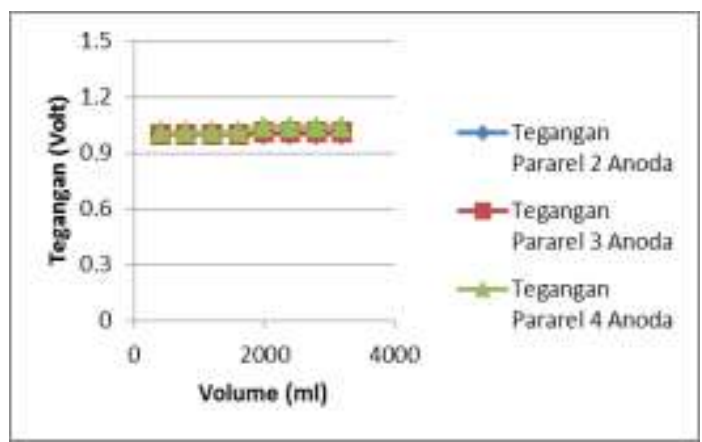

Gambar 8 Hubungan Antara Volume Air dan Tegangan pada Rangkaian Pararel Timbal

Pada gambar 8 pengaruh volume air laut terhadap tegangan tidak berpengaruh. Dimana grafik terbentuk secara linear. Sedangkan nilai tegangan pada masing-masing percobaan Pararel 2, 3, dan 4 tidak mengalami kenaikan seperti hukum kirchoff.

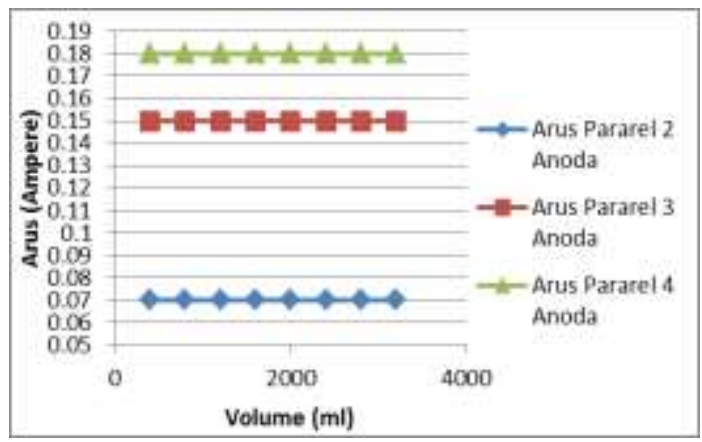

Gambar 9 Hubungan Antara Volume Air dan Arus pada Rangkaian Pararel Timbal

Pada gambar 9 pengaruh volume air laut terhadap Arus tidak berpengaruh. Dimana grafik berbentuk linear. Sedangkan nilai arus pada masing-masing percobaan pararel 2, 3, dan 4 anoda mengalami kenaikan berdasarkan dari hukum kirchoff. Dimana kenaikan terjadi sekitar 0,02-0,04 A 
- Mg-C (Magnesium-Carbon)

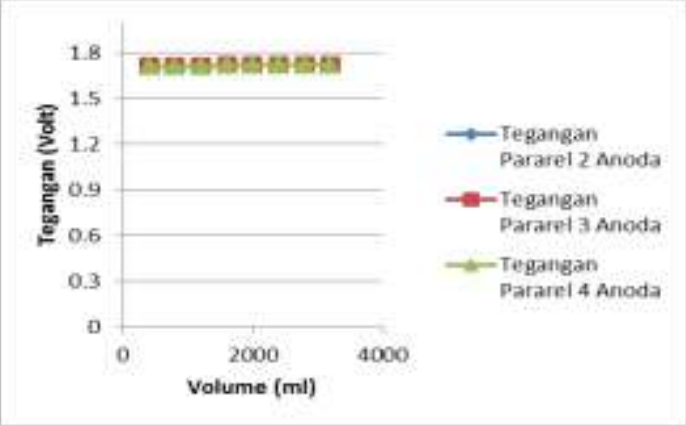

Gambar 10 Hubungan Antara Volume Air dan Tegangan pada Rangkaian Pararel Carbon

Pada gambar 10 pengaruh volume air laut terhadap tegangan tidak berpengaruh. Dimana grafik terbentuk secara linear. Sedangkan nilai tegangan pada masing-masing percobaan seri 2, 3, dan 4 anoda menaiki kenaikan sebesar 1,15-1,3 V

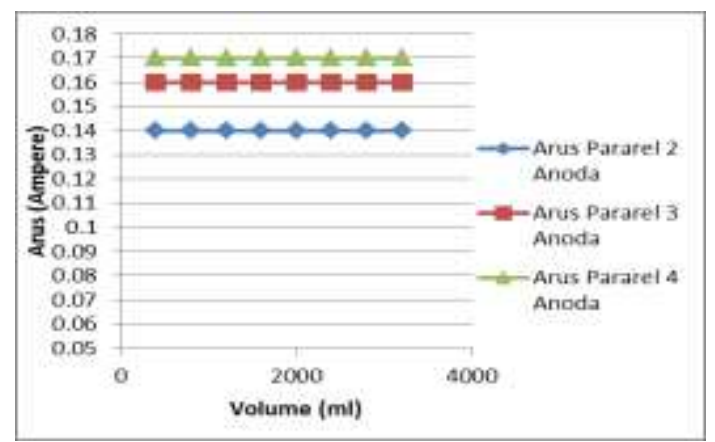

Gambar 11 Hubungan Antara Volume Air dan Arus pada Rangkaian Seri Carbon

Pada gambar 11 pengaruh volume air laut terhadap Arus tidak berpengaruh. Dimana grafik berbentuk linear, dimana ketika volume air ditambahkan maka nilai arus tidak akan berubah.. Sedangkan nilai arus pada masing-masing percobaan seri 2, 3, dan 4 anoda tidak mengalami kenaikan berdasarkan dari hukum kirchoff. Dimana arus tidak akan mengalami kenaikan pada suatu rangkaian seri.

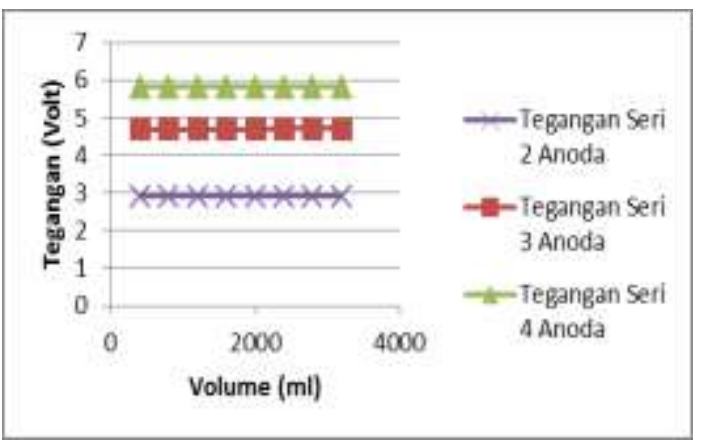

Gambar 12 Hubungan Antara Volume Air dan Arus pada Rangkaian Seri Carbon

Pada gambar 12 pengaruh volume air laut terhadap tegangan tidak berpengaruh. Dimana grafik terbentuk secara linear. Sedangkan nilai tegangan pada masing-masing percobaan
Pararel 2, 3, dan 4 tidak mengalami kenaikan seperti hukum kirchoff. Dimana pada rangkaian pararel tidak akan terjadi kenaikan tegangan.

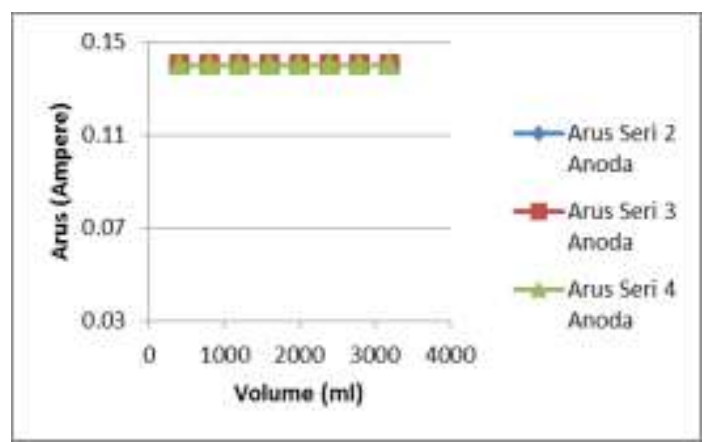

Gambar 13 Hubungan Antara Volume Air dan Arus pada Rangkaian Seri Carbon

Pada grafik diatas pengaruh volume air laut terhadap Arus tidak berpengaruh. Dimana grafik berbentuk linear. Sedangkan nilai arus pada masing-masing percobaan pararel 2, 3, dan 4 anoda mengalami kenaikan berdasarkan dari hukum kirchoff. Dimana kenaikan terjadi akibat bertambahnya jumlah sumber yang dipararelkan.

\section{B. Penyebab Perbedaan Nilai Tegangan Tiap Katoda yang Berbeda}

Perbedaan nilai tegangan tiap katoda diakibatkan oleh nilai E sel yang tercipta berbeda. E sel merupakan E hasil dari reaksi antara Ekatoda dan Eanoda. Dimana biasanya dirumuskan dengan rumus

Esel=Ekatoda-Eanoda

Nilai E tiap-tiap unsur akan memiliki nilai masing-masing berdasarkan sifat bawaan yang dmiliki. Hal ini berdasarakan pada hukum Redoks dalam elektrokimia.

Berikut nilai E tiap-tiap unsur yang digunakan saat penelitian.

$\mathrm{E}_{0} \mathrm{Cu}=-0,34 \mathrm{~V}$ (Tembaga), $\mathrm{E}_{0} \mathrm{Mg}=-2,37 \mathrm{~V}$ (Magnesium), $\mathrm{E}_{0} \mathrm{~Pb}=--$ 0,14 V (Timbal), $\mathrm{E}_{0} \mathrm{C}=-0,08 \mathrm{~V}$ (Carbon).

Maka untuk menentukan nilai Esel yaitu :

- Dengan menggunakan katoda tembaga $(\mathrm{Cu})$ :

Katoda: $\mathrm{Cu}^{2+}+2 \mathrm{e}^{-} \longrightarrow \mathrm{Cu} \quad \mathrm{E}_{0}=-0,34 \mathrm{~V}$

Anoda : $\mathrm{Mg} \longrightarrow \mathrm{Mg}^{2+}+2 \mathrm{e}^{-} \quad \mathrm{E}_{0}=-2,37 \mathrm{~V}$

$\mathrm{Cu}^{2+}+\mathrm{Mg} \longrightarrow \mathrm{Mg}^{2+}+\mathrm{Cu} \quad$ Esel $=2,03 \mathrm{~V}$

Dimana berdasarkan hukum redoks,

Esel $=$ Ekatoda - Eanoda

$$
\begin{aligned}
& =-0,14-(-2,37) \\
& =2,03 \mathrm{~V}
\end{aligned}
$$

- Dengan menggunakan katoda Timbal $(\mathrm{Pb})$ :

Katoda $: \mathrm{Pb}^{2+}+2 \mathrm{e}^{-} \longrightarrow \mathrm{Pb} \quad \mathrm{E}_{0}=-0,14 \mathrm{~V}$

Anoda $: \mathrm{Mg} \longrightarrow \mathrm{Mg}^{2+}+2 \mathrm{e}^{-} \quad \mathrm{E}_{0}=-2,37 \mathrm{~V}$

$$
\overline{\mathrm{Pb}^{2+}+\mathrm{Mg} \longrightarrow \mathrm{Mg}^{2+}+\mathrm{Pb}} \quad \text { Esel=2,23 V }
$$

Dimana berdasarkan hukum redoks,

Esel $\quad=$ Ekatoda - Eanoda

$$
\begin{aligned}
& =-0,14-(-2,37) \\
& =2,23 \mathrm{~V}
\end{aligned}
$$

- Dengan menggunakan katoda Carbon (C) :

Katoda $: \mathrm{C}^{2+}+2 \mathrm{e}^{-} \longrightarrow \mathrm{E}_{0}=-0,08 \mathrm{~V}$ 
Anoda $: \mathrm{Mg} \longrightarrow \mathrm{Mg}^{2+}+2 \mathrm{e}^{-} \quad \mathrm{E}_{0}=-2,37 \mathrm{~V}$

$$
\overline{\mathrm{Pb}^{2+}+\mathrm{Mg} \longrightarrow \mathrm{Mg}^{2+}+\mathrm{Pb}} \text { Esel=2,29 V }
$$

Dimana berdasarkan hukum redoks,

$$
\begin{aligned}
\text { Esel } & =\text { Ekatoda }- \text { Eanoda } \\
& =-0,08-(-2,37) \\
& =2,29 \mathrm{~V}
\end{aligned}
$$

Sehingga carbonlah yang akan menghasilkan tegangan terbesar diantara katoda lain yang digunakan. Hal tersebut

\begin{tabular}{|c|c|c|c|}
\hline Anoda & $\begin{array}{c}\text { Teg. } \\
\text { (Perhitungan) }\end{array}$ & $\begin{array}{c}\text { Teg. } \\
\text { (Praktikum } \\
\text { ) }\end{array}$ & Efisiensi \\
\hline $\begin{array}{c}\text { Cu-Tembaga } \\
\text { (50 lilitan) }\end{array}$ & 2.03 & 1.43 & $70.44 \%$ \\
\hline $\begin{array}{l}\text { Cu-Tembaga } \\
\text { (150 lilitan) }\end{array}$ & 2.03 & 1.49 & $73.40 \%$ \\
\hline $\begin{array}{l}\text { Cu-Tembaga } \\
\text { (200 lilitan) }\end{array}$ & 2.03 & 1.52 & $74.88 \%$ \\
\hline $\begin{array}{l}\text { Cu-Tembaga } \\
\text { (250 lilitan) }\end{array}$ & 2.03 & 1.56 & $76.85 \%$ \\
\hline $\begin{array}{l}\text { Cu-Tembaga } \\
\text { (250 lilitan) }\end{array}$ & 2.03 & 1.62 & $79.80 \%$ \\
\hline $\begin{array}{l}\text { Cu-Tembaga } \\
\text { (Copper) }\end{array}$ & 2.03 & 1.69 & $83.25 \%$ \\
\hline Pb-Timbal & 2.23 & 1.07 & $47.98 \%$ \\
\hline C-Carbon & 2.29 & 1.92 & $83.84 \%$ \\
\hline
\end{tabular}
terbukti pada penelitian dimana dimana nlai terbesar adalah 1,9 $\mathrm{V}$

Tabel 1 Perbadingan tegangan antara perhitungan dan praktikum

Dimana Perhitungan efisiensi= tegangan (praktikum)/tegangan (perhitungan) $\mathrm{x} 100 \%$

Contoh : $1,43 / 2,03 \times 100 \%=70,44 \%$

\section{Perencanaan Prototype}

Dalam pengaplikasian untuk prototype ini, diaplikasikan di kapal nelayan 60 GT dimana hanya menyuplai navigation

\begin{tabular}{|c|c|c|c|c|c|c|c|c|}
\hline \multicolumn{9}{|c|}{$\begin{array}{c}\text { KAPAL LATIH PANGKAH } 60 \text { GT ELECT RIC POWER } \\
\text { BALANCE CALCULATION DC }\end{array}$} \\
\hline \multirow{3}{*}{ No } & \multirow{3}{*}{$\begin{array}{l}\text { Appa } \\
\text { ratus }\end{array}$} & \multirow{3}{*}{$\mathrm{Jml}$} & \multicolumn{2}{|c|}{ Load } & \multicolumn{4}{|c|}{$\begin{array}{c}\text { Demand faktor } \% \\
\text { consumtion power (watt) }\end{array}$} \\
\hline & & & \multirow[b]{2}{*}{$\begin{array}{l}\text { Inp } \\
(\mathrm{w})\end{array}$} & \multirow[b]{2}{*}{$\begin{array}{l}\text { Out } \\
\text { (W) }\end{array}$} & \multicolumn{2}{|c|}{ Berlabuh } & \multicolumn{2}{|c|}{ Berlayar } \\
\hline & & & & & $\begin{array}{l}\text { Con } \\
\text { (W) }\end{array}$ & $\begin{array}{c}\text { Inte } \\
\mathrm{r} \\
(\mathrm{W}) \\
\end{array}$ & $\begin{array}{l}\text { Con } \\
(\mathrm{W})\end{array}$ & $\begin{array}{c}\text { Inte } \\
\mathrm{r} \\
(\mathrm{W}) \\
\end{array}$ \\
\hline & $\begin{array}{l}\text { Gen. } \\
\text { Light } \\
\text { Lamp }\end{array}$ & & & & & & & \\
\hline 1 & $\begin{array}{l}\text { Emer } \\
\text { gency }\end{array}$ & 6 & 14 & 14 & & 84 & & 84 \\
\hline 2 & $\begin{array}{l}\text { Nav. } \\
\text { Light }\end{array}$ & & & & & & & \\
\hline 3 & $\begin{array}{c}\text { Stern } \\
\text { light }\end{array}$ & 1 & 100 & 100 & & 100 & 100 & \\
\hline 4 & $\begin{array}{l}\text { Mast } \\
\text { light }\end{array}$ & 2 & 25 & 25 & & 50 & 50 & \\
\hline 5 & $\begin{array}{l}\text { Side } \\
\text { light }\end{array}$ & 2 & 25 & 25 & & 50 & 50 & \\
\hline
\end{tabular}
deck.

Berikut data kebutuhan listrik kapal pada navigation deck. Tabel 2 Data kebutuhan listrik pada kapal

\begin{tabular}{rrrrrrrr}
\hline \hline 6 & $\begin{array}{c}\text { Anch } \\
\text {. light } \\
\text { Total }\end{array}$ & 1 & 25 & 25 & 25 & & 25 \\
& & & & & $\mathbf{3 0 9}$ & $\mathbf{2 0 0}$ & $\mathbf{1 0 9}$ \\
\hline
\end{tabular}

Untuk mengcover lighting di navigation deck selama 11 jam memerlukan sebanyak 69 blok cell yang dipararelkan, dimana setiap blok cell terdiri dari 13 cell yang diserikan serta mengkonsumsi daya sebesar 3408,6 Wh.

Dimensi prototype untuk yang direncanakan adalah sebesar $130 \mathrm{~cm} \times 175 \mathrm{~cm} \times 20 \mathrm{~cm}$

Berdasarkan hasil diatas maka didesain prototype sedemikian rupa hingga memiliki bentu dan ukuran yang pas.

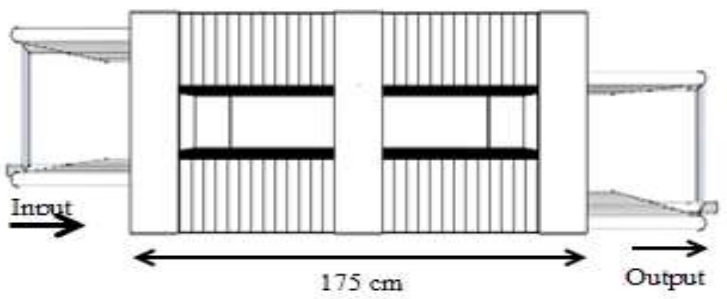

Gambar 14 Dimensi Prototype Pandangan Samping

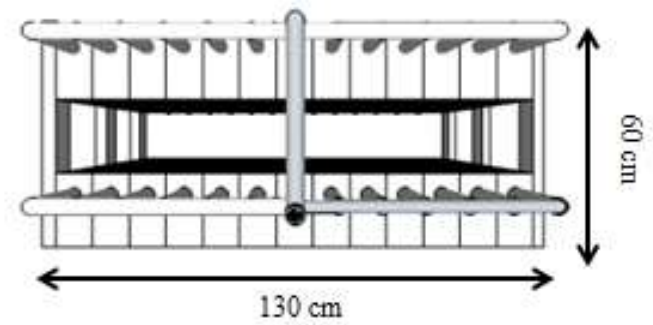

Gambar 15 Dimensi Prototype Pandangan Samping

\section{Apliaksi Pada Kapal}

Pada kapal prototype diletakkan pada engine room

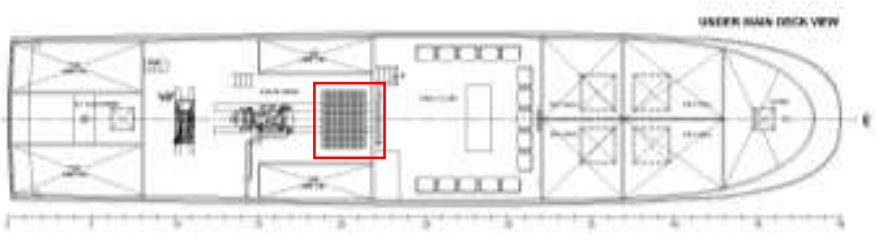

Gambar 16 PeletakanPrototype Pandangan Atas

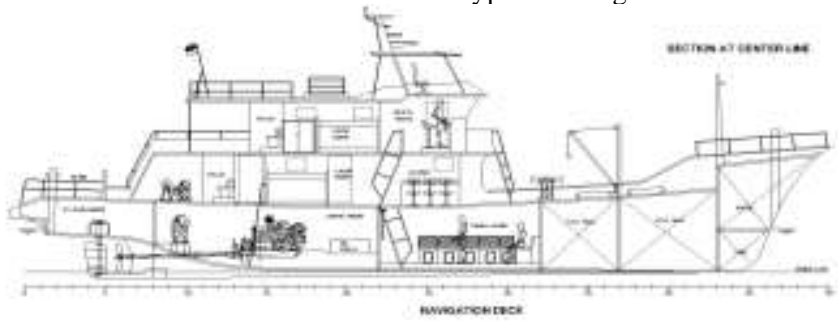

Gambar 17 Peletakan Prototype Pandangan Samping

Selain peletakan pada kapal juga dirancang bagaimana mengenai perencanaan wiring pada kapal. Berikut wiring yang dirangkai 


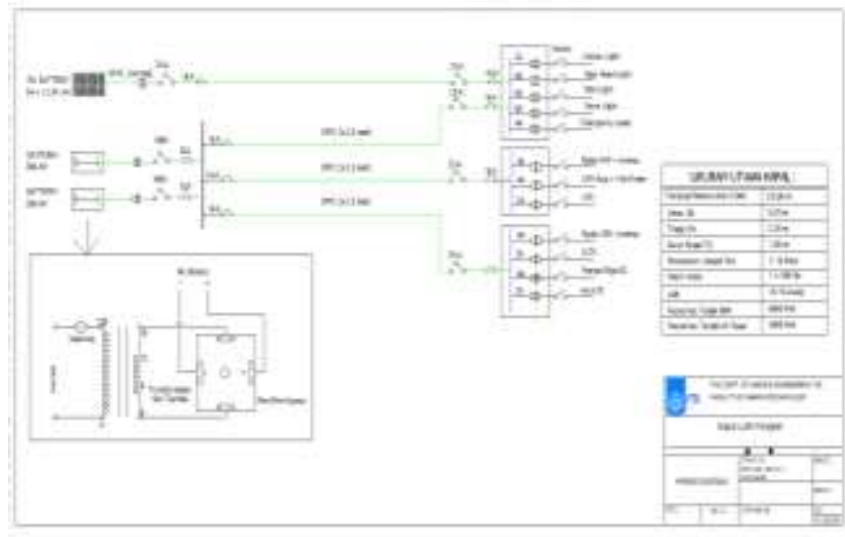

Gambar 18 Wiring Diagaram

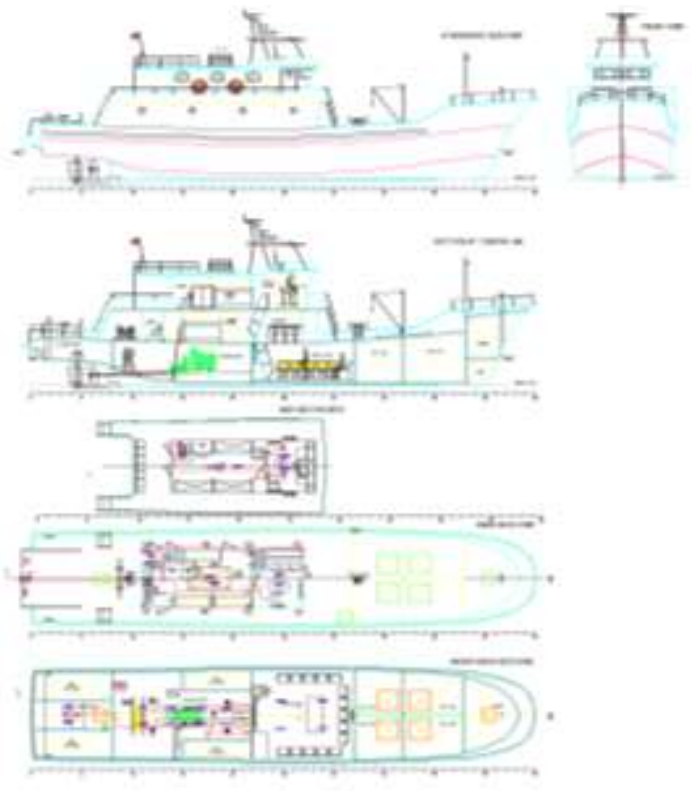

Gambar 19 Wiring Diagaram

\section{E.Analisa Ekonomi}

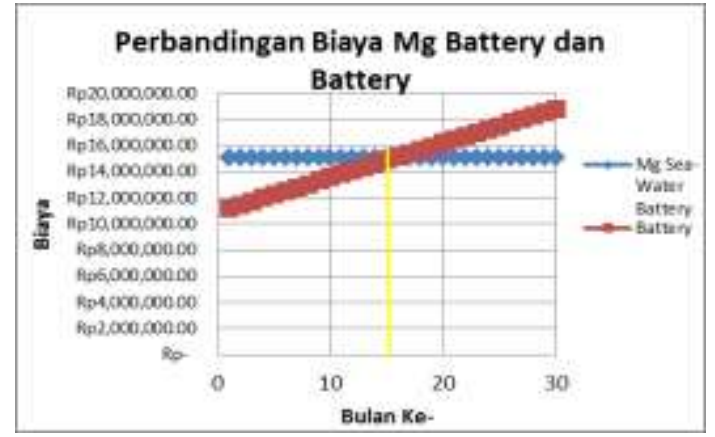

Gambar 20 Perbandingan biaya Mg battery dan battery

Berdasarkan gambar 19 dapat diketahui bahwa pada bulan ke 15 penggunaan battery magnesium akan menyamai biaya dari penggunaan battery biasa yang harus mengisi ulang batterynya. Untuk itu mulai bulan ke-16 penggunaan $\mathrm{Mg}$ battery akan mengalami kuntungan. Dimana keuntungan total yang dimiliki adalah sebesar Rp3,775,000.00 selama 2 tahun

\section{KESIMPULAN}

Untuk mengcover lighting di navigation deck selama 11 jam memerlukan sebanyak 69 blok cell yang dipararelkan, dimana setiap blok cell terdiri dari 13 cell yang diserikan serta mengkonsumsi daya sebesar 3408,6 Wh. Dimensi prototype untuk yang direncanakan adalah sebesar $130 \mathrm{~cm}$ x $175 \mathrm{~cm}$ x 20 $\mathrm{cm}$. Berat prototype ditambah air laut adalah 690,69 Kg.

Pada percobaan lampu (beban) akan menyala hanya dengan menggunakan katoda timbal dan Karbon. Namun katoda terbaik adalah dengan menggunakan karbon, dimana memiliki nilai tegangan $1,92 \mathrm{~V}$ dan arus sebesar 2A dengan menggunakan hambatan dalam, serta efisiensi sebes ar 83,84\%.

Volume air laut tidak berpengaruh terhadap besarnya teganga dan arus, hal tersebut bis a dilihat pada hasil praktikum contoh pada mg-carbon dimana tegangan dan arus bernilai konstan sebesar $1,9 \mathrm{v}$ dan $2 \mathrm{~A}$.

\section{PUSTAKA}

[1] Kaisheva, Anastassia. 2005. Metal-Air Batteries: Research, Development, Application. Proceedings of the International Workshop "Portable and Emergency Energy Sources - from Materials to Systems" 16 - 22 Sept. 2005, Primorsko, Bulgaria

[2] Messina, John.2010. Magnesium Alternatife Power Source. http://phys.org/news/2010-04-magnesium-alternative-powersource.html (diakses tanggal 06-10-2015)

[3] Tadashi, Ishikawa. 2015. Aqua Power Systems Inc. Signs Agreement to Purchase Magnesium Air Fuel Cell Company Aqua Power System Japan. http://aquapowersystems.com/aqua-powersystems-signs-agreement-purchase-magnesium-air-fuel-cellcompany-aqua-power-system-japan/ (diakses tanggal 06-10-2015)

[4] Zhang,Tianran, dkk. 2014. Magnesium-air batteries: from principle to application. http://www.researchgate.net/publication/271382570_Magnesiumair_batteries_From_principle_to_application (diakses tanggal 1310-2015) 